\title{
Genetic diversity and population structure of Chilean blueberry Gaultheria pumila (L.f.) D.J. Middleton (Ericaceae)
}

\author{
José Pico-Mendoza ${ }^{1 *}$, Rolando Garcia-Gonzáles ${ }^{2}$, Karla Quiroz $^{3}$, Miryan Pinoargote ${ }^{1}$, \\ Yohaily Rodríguez-Alvarez ${ }^{4}$, Borys Chong ${ }^{2}$, Pablo Cáceres-Ruz ${ }^{2}$, Hugo Pino ${ }^{3}$, Peter D.S. Caligari ${ }^{5}$, \\ and Basilio Carrasco ${ }^{4}$
}

\begin{abstract}
${ }^{1}$ Universidad Técnica de Manabí, Facultad de Ingeniería Agronómica, Vía Santa Ana- km 13.5, Manabí, Ecuador. *Corresponding author (jwpico@utm.edu.ec).

${ }^{2}$ Sociedad de Investigación y Servicios, BioTECNOS Ltda., Camino a Pangal, km 2.5, San Javier, Chile.

${ }^{3}$ Universidad Católica del Maule. Facultad de Ciencias Agrarias y Forestales, Av. San Miguel 3605, Talca, Chile.

${ }^{4}$ Pontificia Universidad Católica de Chile, Facultad de Agronomía e Ingeniería Forestal, Av. Vicuña Mackenna 4860, Santiago, Chile.

${ }^{5}$ Verdant BioScience Pte Ltd., 18 Duxton Hill 089601, Singapore.
\end{abstract}

Received: 21 February 2020; Accepted: 18 May 2020; doi:10.4067/S0718-58392020000300413

\begin{abstract}
Gaultheria pumila (L.f.) D.J. Middleton is a native shrub of Chile that produces edible berry fruits. This species is related to the cultivated Vaccinium species; for this reason it is currently called Chilean blueberry locally. Although G. pumila has important attributes, it has been largely ignored, and remains an unexplored genetic resource. This study investigates the genetic diversity to support the efforts to domesticate the species. Sampling was carried out in 11 sites collected from four Regions of Chile. In total, 160 individuals were collected and analyzed using a set of 10 simple sequence repeats (SSRs) markers. The average observed heterozygosity was Ho $=0.50$, while the expected heterozygosity was $\mathrm{He}=0.46$. The fixation index $\left(\mathrm{F}_{\mathrm{IS}}\right)$ showed an average of -0.07 , and the proportion of differentiation among populations $\left(\mathrm{F}_{\mathrm{ST}}\right)$ was 0.11 . The average level of polymorphic loci in all populations (PPL) was $96.97 \%$. AMOVA showed that the genetic diversity among populations was very low $(\Phi P T=6 \%)$. Significant correlations were found between genetic and geographic distance. Multivariate and Bayesian analyses identified two genetic groups. These results will be very useful to support the efforts to domesticate and increase the value of this species.
\end{abstract}

Key words: Allele frequency, AMOVA, Gaultheria pumila, genetic diversity, heterozygosity.

\section{INTRODUCTION}

The genus Gaultheria belongs to the family Ericaceae; it is adapted to tropical and temperate climates. It is important in terms of functional human nutrition, as many of its species contain high levels of flavonoids and simple phenols (Villagra et al., 2014) and also have different compounds with anti-rheumatic effects (Liu et al., 2013). Gaultheria pumila is diploid, but other species of Gaultheria are tetraploid or hexaploid (Mukhopadhyay et al., 2016). The chromosome numbers in some species of the tribe Gaultherieae are $2 n=22,24,26,36,44,48,66,88$, and 96, indicating that polyploid species have appeared frequently during its evolutionary history (Middleton and Wilcock, 1990; Lu et al., 2019). The distribution of this genus in the American continent ranges from Mexico to Argentina (Luteyn, 2002). In Chile, 12 species of this genus have been reported, including G. pumila (Teillier and Escobar, 2013), which are distributed from the Metropolitan Region $\left(33^{\circ} \mathrm{S}\right.$ lat) to the Magallanes y la Antártida Chilena Region (53 S lat). However, other authors express that G. pumila 
is distributed from Valparaíso Region (Rodriguez et al., 2018). The species G. pumila is a dioecious evergreen shrub, commonly known locally as "chaura" and "mutilla del zorro". Currently, chaura is considered as the Chilean blueberry due to its characteristics; its properties are similar to those of Vaccinium spp. It has been observed that G. pumila has a high degree of adaptability to extreme conditions and can even be found under snow in the winter or exposed to high temperatures and UV radiation during the summer. This species has a symbiotic mycorrhizal association (Medina et al., 2009); it is a colonizing plant, being one of the first to appear in areas affected by disasters (Luteyn, 2002). Gaultheria pumila is exploited by the native people for food and medicines (Dominguez, 2010). Fruits have different forms (globose or ovoid) with sizes between 6 and $12 \mathrm{~mm}$ in diameter and in white, pink and red colors (Figure 1). The fruits are very aromatic and tasty; they are flattened at the apex, fleshy, and have an intense flavor and different phytochemical content (Villagra et al., 2014). The phytochemical content of G. pumila depends on the genotype; red fruit have an average value

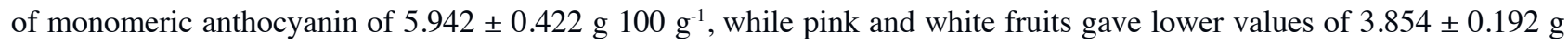
and 0.626.2 $\pm 0.41 \mathrm{~g}$ (Villagra et al., 2014). Morphological differences are easily detected between individuals within the natural populations of G. pumila, so it becomes essential to study and identify phenotypes in germplasm collections for conservation, selection, and breeding (Ahmad et al., 2010). All these attributes of G. pumila make this species an interesting target for domestication, due to its potential use as a functional food. Unfortunately, little information is available about the propagation of this species out of its natural habitat, culture techniques, nutritional requirements, and even less about its genetic composition, thus this species remains an unexploited genetic resource. To take advantage of this resource species, it is necessary to develop basic studies on its genetic composition and population structure (Gepts, 2004). Molecular markers such as simple sequence repeats (SSRs) or microsatellites are a robust tool for population genetic studies in G. pumila. Today SSRs are available for several plant species to assess genetic diversity (Hoshino et al., 2012). In the family Ericaceae, SSRs have been used to perform molecular studies in Rhododendron delavayi (Wang et al., 2010), R. simsii (Wang et al., 2016) and R. ferrugineum (Delmas et al., 2011). In the genus Vaccinium, SSRs have allowed the evaluation of more than 1700 accessions from the National Clonal Germplasm Repository, Corvallis, Oregon, of the Agricultural Research Service of the United States Department of Agriculture (Bassil, 2012). This study aimed to determine the genetic diversity of G. pumila through its natural distribution. The purpose of this study was to support domestication programs and select potential genotypes for breeding programs.

Figure 1. Variability in morphometric traits in fruits of Gaultheria pumila collected in different sites in the volcano Villarrica, La Araucanía Region.
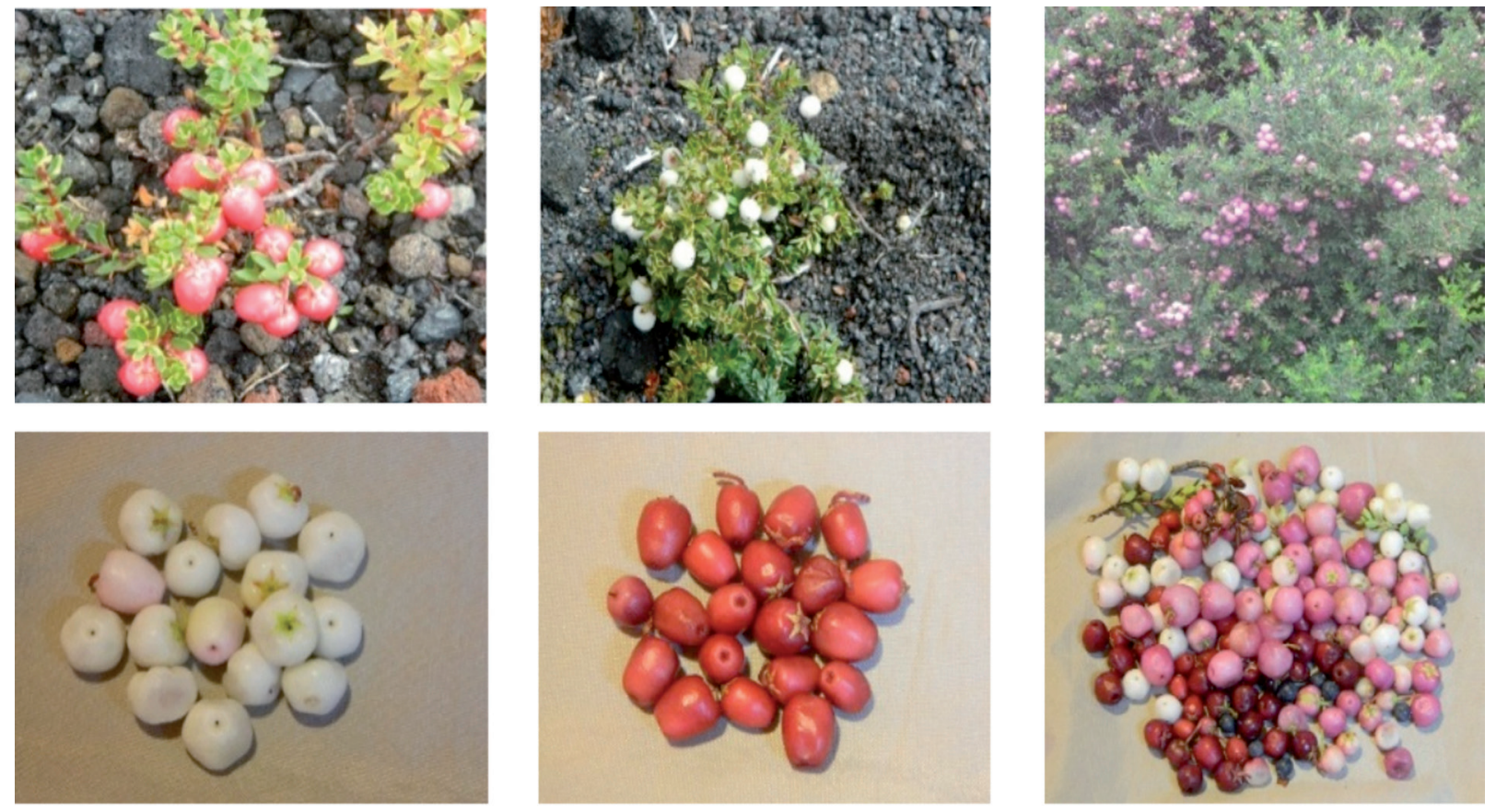


\section{MATERIALS AND METHODS}

\section{Plant material and DNA extraction, PCR amplification and microsatellite analysis}

Leaves of 160 shrubs of Gaultheria pumila were collected from 11 sites distributed in four of Chile's administrative Regions: Maule, La Araucanía, Los Lagos, and Magallanes y la Antártida Chilena (Table 1). Samples were collected from March to August 2013, from bushes separated by at least $10 \mathrm{~m}$. Every site was georeferenced using the Global Positioning System (GPS). Leaf samples were immediately conserved in ice and transported to the laboratory, where they were stored at $-80^{\circ} \mathrm{C}$ until DNA extraction.

A sample of $200 \mathrm{mg}$ of young leaves of G. pumila was placed in $2.0 \mathrm{~mL}$ tubes and frozen in liquid nitrogen. Leaf samples were macerated with the Precellis 24 and Cryollys systems (Bertin Technologies, Montigny-le-Bretonneux, France) and centrifuged at $6000 \mathrm{rpm}$ in three cycles of $30 \mathrm{~s}$. Total DNA extraction of all samples was performed using the cetyltrimethylammonium bromide (CTAB) protocol (Doyle and Doyle, 1990). Ten simple sequence repeat (SSR) loci were used according to Garcia-Gonzales et al. (2018); their main characteristics are shown in Table 2. Polymerase chain reaction (PCR) was carried out using the following steps: denaturation at $94{ }^{\circ} \mathrm{C}$ for $5 \mathrm{~min}$; annealing for each primer pair (Table 2) for $45 \mathrm{~s}$, extension at $72{ }^{\circ} \mathrm{C}$ for $45 \mathrm{~s}$. This cycle was repeated 30 times, then a final extension at $72{ }^{\circ} \mathrm{C}$

Table 1. Location of the sites where Gaultheria pumila was sampled within its range in Chile.

\begin{tabular}{|c|c|c|c|}
\hline Regions & Nr samples & Sites & Geographical coordinates \\
\hline Maule (Reserva Nacional Radal Siete Tazas) & 10 & Parque Inglés (PI) & $35^{\circ} 29^{\prime} 420^{\prime \prime} \mathrm{S} ; 70^{\circ} 56^{\prime} 667^{\prime \prime} \mathrm{W}$ \\
\hline \multirow[t]{5}{*}{ La Araucanía (Villarrica) } & 15 & Parque de las Araucarias (PT) & $39^{\circ} 21^{\prime} 570^{\prime \prime} \mathrm{S} ; 71^{\circ} 57^{\prime} 865^{\prime \prime} \mathrm{W}$ \\
\hline & 7 & El Playón (PZ) & $39^{\circ} 34^{\prime} 463^{\prime \prime} \mathrm{S} ; 71^{\circ} 28^{\prime} 509^{\prime \prime} \mathrm{W}$ \\
\hline & 22 & El Mirador (EM) & $39^{\circ} 23^{\prime} 209^{\prime \prime} \mathrm{S} ; 71^{\circ} 58^{\prime} 006^{\prime \prime} \mathrm{W}$ \\
\hline & 15 & Centro de sky (CK) & $39^{\circ} 22^{\prime} 915^{\prime \prime} \mathrm{S} ; 71^{\circ} 55^{\prime} 565^{\prime \prime} \mathrm{W}$ \\
\hline & 15 & Parque Nacional Conguillío (CN) & $39^{\circ} 34^{\prime} 400^{\prime \prime} \mathrm{S} ; 71^{\circ} 46^{\prime} 973^{\prime \prime} \mathrm{W}$ \\
\hline \multirow[t]{2}{*}{ Los Lagos } & 9 & Parque Nacional Puyehue (PN) & $40^{\circ} 40^{\prime} 538^{\prime \prime} \mathrm{S} ; 72^{\circ} 07^{\prime} 103^{\prime \prime} \mathrm{W}$ \\
\hline & 19 & Camino Puyehue $(\mathrm{CH})$ & $40^{\circ} 40^{\prime} 599^{\prime \prime} \mathrm{S} ; 72^{\circ} 344^{\prime} 501^{\prime \prime} \mathrm{W}$ \\
\hline \multirow{3}{*}{ Magallanes y la Antártida Chilena } & 20 & Punta Arenas (PA) & $53^{\circ} 9^{\prime} 413^{\prime \prime} \mathrm{S} ; 71^{\circ} 1^{\prime} 437^{\prime \prime} \mathrm{W}$ \\
\hline & 11 & Reserva Nacional Magallanes (RM) & $53^{\circ} 10^{\prime} 490^{\prime \prime} \mathrm{S} ; 71^{\circ} 10^{\prime} 120^{\prime \prime} \mathrm{W}$ \\
\hline & 17 & Reserva Nacional Laguna Parrillar (PL) & $53^{\circ} 24^{\prime} 140^{\prime \prime} \mathrm{S} ; 71^{\circ} 15^{\prime} 099^{\prime \prime} \mathrm{W}$ \\
\hline
\end{tabular}

Table 2. Characteristics of $\mathbf{1 0}$ microsatellite markers and specific primer pairs developed for Gaultheria pumila.

\begin{tabular}{|c|c|c|c|c|c|}
\hline Locus & Primer sequences $\left(5^{\prime}-3^{\prime}\right)$ & Repeat motif & Allele size & $\begin{array}{l}\text { Annealing } \\
\text { temperature }\end{array}$ & $\begin{array}{l}\text { GenBank } \\
\text { accession }\end{array}$ \\
\hline GP.7 & F: CGCATTCACTCACCCTCTCA & (ACTC)4 & 360 & 52.1 & KX719822 \\
\hline GP.9 & $\begin{array}{l}\text { R: TGGTTGGTGAAGGCTTTGGA } \\
\text { F: ACCCGCTCTAGATCCTCTCT } \\
\text { R: AGGGGGAGTAATCAAGCCTC }\end{array}$ & (T) 10 & $378-380$ & 60.5 & KX719823 \\
\hline GP.10 & $\begin{array}{l}\text { F: GGGTACGGCGTAGTGGTAAT } \\
\text { R: TCGTACAAAACCGCCCTCAA }\end{array}$ & $(\mathrm{AT}) 8$ & $323-327$ & 60.5 & KX719824 \\
\hline GP.12 & $\begin{array}{l}\text { F: AGGATTATAGAGAGCCAGGTGGA } \\
\text { R: CAGAAGACGAAATCGAAGCCG }\end{array}$ & (CTT) 4 & 198-201 & 52.1 & KX719825 \\
\hline GP.13 & $\begin{array}{l}\text { F: AGAGTAAGAGCTCTCTTCCGA } \\
\text { R: GCAGACTCGAATCGGCAGTA }\end{array}$ & (ATT) 4 & $161-278$ & 52.1 & KX719826 \\
\hline GP.14 & $\begin{array}{l}\text { F: GCATAGCCCGGTTGTCAAAC } \\
\text { R: ACCGAAAGATCCGACCATCG }\end{array}$ & (ACGC)4 & $196-228$ & 52.1 & KX719827 \\
\hline GP.15 & $\begin{array}{l}\text { F: GGGCTGCTGCTCAATCAATT } \\
\text { R: ACCCGCTTCAAGTCATGATGA }\end{array}$ & (T) 10 & $347-351$ & 52.1 & KX719828 \\
\hline GP.16 & $\begin{array}{l}\text { F: GCTATTTCTAGGGCCGGACC } \\
\text { R: GCACAATACATAGATTCTGGATCGA }\end{array}$ & (AT)6 & $281-283$ & 52.1 & KX719829 \\
\hline GP.17 & $\begin{array}{l}\text { F: GAGAGAAATCCACCAGGGCA } \\
\text { R: CAAGCGGACGACGTATACGA }\end{array}$ & (T)10 & 202-205 & 60.5 & KX719830 \\
\hline GP.18 & $\begin{array}{l}\text { F: ACCGAAAGATCCGACCATCG } \\
\text { R: GCATAGCCCGGTTGTCAAAC }\end{array}$ & $(\mathrm{GCGT}) 4$ & $192-228$ & 52.1 & KX719831 \\
\hline
\end{tabular}

GenBank is a comprehensive public database of nucleotide sequences and supporting bibliographical and biological annotation; built and distributed by the National Center for Biotechnology Information (NCBI), a division of the National Library of Medicine (NLM), Bethesda, Maryland, USA (Benson et al., 2009). 
for $30 \mathrm{~min} . \mathrm{PCR}$ were carried out in a final volume of $20 \mu \mathrm{L}$ reaction mixture containing $10 \mathrm{ng}$ DNA template, $0.15 \mathrm{mM}$ each dNTP, $1 \mathrm{X}$ Taq polymerase reaction buffer, $1.5 \mathrm{mM} \mathrm{MgCl}_{2}, 0.025 \mu \mathrm{M}$ forward primers, $0.1 \mu \mathrm{M}$ reverse primer, $0.1 \mu \mathrm{M}$ M13 primer and $0.35 \mathrm{U}$ Taq DNA polymerase. PCR products were separated by capillary electrophoresis in an ABI 3130xl Prism Genetic Analyzer with POP-7 polymer (Life Technologies, Foster City, California, USA). Allele sizes were calculated with GeneMapper software v 4.0 (Applied Biosystems, Foster City, California, USA).

\section{Statistical analysis}

The genetic diversity index was estimated for each microsatellite locus and each sample. The POPGENE v. 1.31 software (Yeh et al., 1999) was used to calculate the genetic parameters (percentage of polymorphic loci, number of alleles, heterozygosity). The inbreeding coefficients for each locus $\left(\mathrm{F}_{\mathrm{IT}}, \mathrm{F}_{\mathrm{ST}}, \mathrm{F}_{\mathrm{IS}}\right)$ were estimated by resampling using the jackknife method with FSTAT v. 2.9.3 (Goudet, 1994). Null allele (F Null) estimation was calculated using CERVUS (Kalinowski et al., 2007). Deviation from the Hardy-Weinberg equilibrium (EHW) and linkage disequilibrium (LD) were determined with GenePop v. 4.2 with the sequential Bonferroni correction carried out for all SSR loci. Analysis of molecular of variance (AMOVA) was applied to estimate the variance components of individuals among and within the sample sites using GenAlex software (Peakall and Smouse, 2006). The Mantel test was also carried out to determine the correlation between genetic and geographic distance. Analysis of population genetic structure was carried out through the Bayesian clustering method with the STRUCTURE 2.3.3 software (Pritchard et al., 2000) Genetic clusters (K=1-11) were evaluated with ten runs per $\mathrm{K}$ value. The initial burn-in period was set to 100000 with $1000000 \mathrm{MCMC}$ iterations under the admixture model. The best K value was estimated by STRUCTURE HARVESTER software (Earl and vonHoldt, 2012).

\section{RESULTS AND DISCUSSION}

\section{Genetic diversity analysis}

Ten polymorphic SSRs were applied to evaluate 160 samples of G. pumila from the different natural populations (Table 2). The average of null allele frequency was very low for all loci (mean 0.10). However, SSR loci GP12 and GP16 showed significant heterozygosity; they also had the highest values of null alleles. The neutral test for all loci showed no evidence of positive selection. In the analysis of all possible binary combinations, none showed significant linkage disequilibrium (LD) after applying the Bonferroni correction ( $\mathrm{p}<0.00003046)$. The average number of alleles (Na) was 4.20; the highest value was observed in locus GP18 (10) and the lowest value in locus GP7 (1.0). The mean of observed heterozygosity (Ho) and expected heterozygosity (He) were 0.50 and 0.46 , respectively. Ho ranged from 0.0 (GP7) to 1.0 (GP17); He ranged from 0.0 (GP7) to 0.74 (GP13). The inbreeding coefficient $\left(\mathrm{F}_{\mathrm{IS}}\right)$ showed negative values for the loci GP7, GP10, GP13, GP14, GP18, and five positive values for GP9, GP12, GP15, GP16, and GP17. The average $\mathrm{F}_{\mathrm{IS}}$ value was -0.07 and was significantly different from zero $(\mathrm{P}=0.0007)$. Values of proportion of differentiation among populations $\left(\mathrm{F}_{\mathrm{ST}}\right)$ ranged from 0.00 (GP7) to 0.39 (GP16) (Table 3).

Table 3. Estimates of genetic diversity (per locus) in Gaultheria pumila based on 10 SSR loci. Observed number of alleles $(\mathrm{Na})$, observed heterozygosity $(\mathrm{Ho})$, expected heterozygosity $(\mathrm{He})$, inbreeding coefficient $\left(\mathrm{F}_{\mathrm{IS}}\right)$, proportion of differentiation among populations $\left(\mathrm{F}_{\mathrm{ST}}\right)$, Hardy-Weinberg equilibrium $(\mathrm{HW})$, frequency of null alleles $\mathrm{F}$ (Null).

\begin{tabular}{lccccccc}
\hline Locus & Na & Ho & He & $\mathrm{F}_{\text {IS }}$ & $\mathrm{F}_{\text {ST }}$ & HW & F (Null) \\
\hline GP7 & 1 & 0.00 & 0.00 & -0.20 & 0.00 & $\mathrm{~ns}$ & 0.00 \\
GP9 & 2 & 0.38 & 0.31 & 0.27 & 0.04 & $*$ & 0.40 \\
GP10 & 4 & 0.98 & 0.57 & -0.77 & 0.04 & $*$ & -0.25 \\
GP12 & 3 & 0.03 & 0.51 & 0.93 & 0.11 & $*$ & 0.88 \\
GP13 & 6 & 0.94 & 0.74 & -0.44 & 0.13 & $*$ & -0.13 \\
GP14 & 8 & 0.39 & 0.34 & -0.29 & 0.11 & $\mathrm{~ns}$ & -0.10 \\
GP15 & 3 & 0.44 & 0.57 & 0.36 & 0.10 & $*$ & 0.30 \\
GP16 & 3 & 0.25 & 0.54 & 0.24 & 0.39 & $*$ & 0.34 \\
GP17 & 2 & 1.00 & 0.53 & -0.80 & 0.12 & $\mathrm{~ns}$ & 0.30 \\
GP18 & 10 & 0.61 & 0.53 & -0.21 & 0.04 & $\mathrm{~ns}$ & -0.09 \\
Mean & 4.2 & 0.50 & 0.46 & -0.07 & 0.11 & & 0.11 \\
\hline
\end{tabular}

"Significant at $\mathrm{p}=0.01 ;$ ns: nonsignificant. 
The lowest percentage of polymorphic loci (83\%) was found in the populations of Parque Inglés (PI) in the Maule Region and Parque de Araucarias (PT) in La Araucanía Region (Table 4). The mean value of observed heterozygosity $(\mathrm{Ho}=0.54)$ was greater than the expected heterozygosity $(\mathrm{He}=0.47)$. The Ho ranged from 0.46 in PT, La Araucanía Region, to 0.66 in the Reserva de Magallanes (RM), Magallanes y la Antártida Chilena Regions. The inbreeding coefficient $\left(\mathrm{F}_{I S}\right)$ was positive only for two populations, Parque Nacional Puyehue (PN; 0.03$)$ and Camino Puyehue $(\mathrm{CH} ; 0.16)$. Other populations showed negative $\mathrm{F}_{\mathrm{IS}}$ values. The average $\mathrm{F}_{\mathrm{IS}}$ value for Gaultheria was significantly negative $(-0.16 ; \mathrm{p}=0.01)$, indicating excess heterozygosity.

SSR markers have been widely used to detect genetic diversity in the different blueberries of the family Ericaceae, especially in Vaccinium. However, this is the first time that this kind of study, using SSR markers, has been carried out in any wild species of the genus Gaultheria. Genetic diversity per locus in Chilean blueberry showed that Ho ranged from 0.0 to 1.0, and He ranged from 0.0 to 0.74 . These results are similar to those reported in other Ericaceae, such as Rhododendron simsii (Wang et al., 2016) and R. ferrugineum (Delmas et al., 2011), where He and Ho showed a broad range of variation. An excess of heterozygosity was observed, which can be explained by its high levels of gene flow ( $\mathrm{Nm}$ $=2.06$ ) due to its sexual reproduction by outcrossing. In contrast, only four loci (GP9, GP12, GP15, and GP16) showed a significant heterozygote deficit; a high frequency of null alleles could explain these results in part. According to OddouMuratorio et al. (2009), heterozygous deficiency can be affected by null alleles, which are a common cause of apparent deviations from Hardy-Weinberg equilibrium at SSR loci and can overestimate the inbreeding coefficient.

The descriptive statistics for diversity genetic over all loci were moderate $(\mathrm{Na}=4.20, \mathrm{Ho}=0.50, \mathrm{He}=0.46)$. These results could be explained by the number of individuals sampled, low polymorphism of the SSRs, isolation by distance, or the influence of factors from forest fragmentation (Kramer et al., 2008). These variability levels are similar to those reported in species with high economic and ornamental values, such as cherry Prunus pseudocerasus Lindl. (Chen et al., 2015) and Prunus persica (Pérez et al., 2020). Bantawa et al. (2011) found a high level of polymorphism (68.52\%) in Gaultheria fragantissima using RAPD. This level of polymorphism in this related species was later confirmed using ISSR markers (82.82\%) (Apte et al., 2006).

In G. shallon (Wilkin et al., 2005), the percentage of polymorphic loci detected with amplified fragment length polymorphism (AFLP) reached $89 \%$. These similarities with G. pumila could be explained by the fact that they are all open-pollinated species, typically inhabiting extreme environmental conditions. These authors considered that this level of genetic diversity could be an excellent basis to begin domestication based on the selection of wild genotypes. Some wild species have been domesticated, such as Vaccinium macrocarpon (Fajardo et al., 2013), V. sieboldii, V. ciliatum, V. oldhamii, V. bracteatum (Hirai et al., 2010), and other species such as grape (Emanuelli et al., 2013) as well as Chilean native species such as Fragaria chiloensis (Carrasco et al., 2013), and Vasconcellea sp. (Carrasco et al., 2009).

Table 4. Descriptive statistics for all loci for each population of Gaultheria pumila. Sites where samples were taken, number of alleles $(\mathrm{Na})$, observed heterozygotes $(\mathrm{Ho})$, expected heterozygotes $(\mathrm{He})$, inbreeding coefficient $\left(\mathrm{F}_{\mathrm{IS}}\right)$, percentage of polymorphic loci (PPL), number of effective alleles (Ne), Shannon index (I).

\begin{tabular}{lcccccccc}
\hline Regions & Sites & $\mathrm{Na}$ & $\mathrm{Ho}$ & $\mathrm{He}$ & $\mathrm{F}_{\mathrm{IS}}$ & $\mathrm{PPL}$ & $\mathrm{Ne}$ & $\mathrm{I}$ \\
\hline Maule & $\mathrm{PI}$ & 3.16 & 0.62 & 0.45 & -0.39 & $83 \%$ & 2.07 & 0.77 \\
La Araucanía & $\mathrm{PT}$ & 2.50 & 0.46 & 0.38 & -0.21 & $83 \%$ & 1.75 & 0.60 \\
& $\mathrm{PZ}$ & 2.33 & 0.61 & 0.45 & -0.39 & $100 \%$ & 1.80 & 0.65 \\
& $\mathrm{EM}$ & 3.66 & 0.50 & 0.47 & -0.06 & $100 \%$ & 2.02 & 0.80 \\
& $\mathrm{CK}$ & 3.50 & 0.53 & 0.53 & -0.008 & $100 \%$ & 2.36 & 0.89 \\
& $\mathrm{CN}$ & 2.33 & 0.48 & 0.37 & -0.32 & $100 \%$ & 1.69 & 0.57 \\
Los Lagos & $\mathrm{PN}$ & 2.16 & 0.54 & 0.52 & 0.03 & $100 \%$ & 1.90 & 0.68 \\
& $\mathrm{CH}$ & 3.00 & 0.47 & 0.56 & 0.16 & $100 \%$ & 2.49 & 0.91 \\
Magallanes y la Antártida Chilena & $\mathrm{PA}$ & 2.83 & 0.49 & 0.45 & -0.10 & $100 \%$ & 1.89 & 0.72 \\
& $\mathrm{RM}$ & 2.83 & 0.66 & 0.50 & -0.33 & $100 \%$ & 2.14 & 0.79 \\
& $\mathrm{PL}$ & 3.16 & 0.58 & 0.51 & -0.12 & $100 \%$ & 2.08 & 0.84 \\
& Mean & 2.86 & 0.54 & 0.47 & -0.16 & $96.97 \%$ & 2.02 & 0.75 \\
\hline
\end{tabular}

Maule Region: Parque Inglés (PI); La Araucanía Region: Parque de las Araucarias (PT), El Playón (PZ), El Mirador (EM), Centro de sky (CK), Parque Nacional Conguillío (CN); Los Lagos Region: Parque Nacional Puyehue (PN), Camino Puyehue (CH); Magallanes y la Antártida Chilena Region: Punta Arenas (PA), Reserva Nacional Magallanes (RM), Reserva Nacional Laguna Parrillar (PL). 
The inbreeding coefficient $\left(\mathrm{F}_{\mathrm{IS}}\right)$ had an average negative value and showed an excess of heterozygosity that could be due to the immigration process or absence of selfing (Balloux, 2004). These negative values suppose that the reproductive biology of the species probably causes the excess of heterozygosity since it is open pollinating. Gene flow is also due to the mobility of wild animals that eat fruit and disperse their seeds, causing a continuous mixture in the different demes. In the 4 years of this study we observed pollinator insects, especially Bombus spp., as well as wild animals, such as rabbits, birds, lizards and foxes feeding on the fruits. This species is also a food source for foxes in the wild; G. pumila is commonly named mutilla del zorro.

\section{Population structure and genetic differentiation}

The analysis of molecular variance (AMOVA) showed that a high proportion of the variation was observed within populations (94\%) with the remaining variance (6\%) being attributed to the genetic differences between populations (Table 5).

The Mantel test showed a significant positive correlation between genetic distance and geographic distance (correlation coefficient $\mathrm{Rxy}=0.718, \mathrm{p}=0.010$ ). These results would suggest that there is isolation by distance. The organization between populations, based on Nei's genetic distance, found the maximum value $(0.55)$ between the populations of Parque Nacional Conguillío $(\mathrm{CN})$ and $\mathrm{RM}$, and the minimum genetic distance (0.01) between the populations of $\mathrm{CN}$ and Playón (PZ).

The Bayesian clustering indicated that the maximum $\Delta K$ was obtained at $K=2$ (Figure 2). The $K$ values between 3 and 11 showed complex admixture that did not fit the criteria to be considered as genetic groups. The two genetic groups identified clustered individuals from all population collection points except in PI in Maule Region. The populations from La Araucanía to Magallanes Regions showed a high degree of admixture $(\mathrm{Q}$ values $<0.8)$, based on results obtained from Bayesian model-based structure analysis of 160 samples of $G$. pumila. The sites evaluated were sampled from the Maule to Magallanes y la Antártida Chilena Regions of Chile, covering part of its distribution. The northern population was collected from the Maule Region, and the Southern population was collected from the Magallanes Region, the limits of the species distribution. The high level of variation within populations indicating that most of the genetic variation is explained by the genetic exchange among individuals. There was no evidence of genetic differentiation due to geographically isolated groups.

These results coincide with previously reported observations that found a high level of phenotypic variation in natural populations of this species (Villagra et al., 2014). This pattern of distribution of the genetic variability is very similar to that detected for "maqui" (Aristotelia chilensis [Molina] Stuntz) (Salgado et al., 2017), a wild berry native to Chile which is currently subject to an intense domestication process. Indeed, it was found in this species that $95 \%$ of the genetic variability was within populations and 5\% between populations, remarkably similar to G. pumila in Chile. Bayesianbased analysis of genetic grouping detected only two groups in G. pumila. The first and second group contains individuals from the populations belonging to Maule, La Araucanía, Los Lagos, and Magallanes Regions, which suggests a consistent mixture of alleles, showing a constant dynamism that does not allow differentiation. However, positive correlation between distance and genetic distance was detected by the Mantel test, suggesting lower genetic connectivity between the populations belonging to extreme Regions. Consequently, the isolation of these populations can affect the pollen dispersal and therefore the gene flow.

Table 5. AMOVA in different natural populations of Gaultheria pumila, Chile.

\begin{tabular}{lcccccc}
\hline Sources of variation & df & $\begin{array}{c}\text { Sum of } \\
\text { squares }\end{array}$ & $\begin{array}{c}\text { Est. } \\
\text { variance }\end{array}$ & $\begin{array}{c}\text { Percentage } \\
\text { variation }\end{array}$ & $\begin{array}{c}\text { Fixation } \\
\text { index }\end{array}$ & P value \\
\hline Among populations & 10 & 18.836 & 0.062 & $6 \%$ & & \\
Within populations & 149 & 148.562 & 0.997 & $94 \%$ & 0.058 & 0.001 \\
Total & 159 & 167.398 & 1.059 & & & \\
\hline
\end{tabular}


Figure 2. Genetic groups estimated by Bayesian analysis. A) $\Delta K$ estimates of the posterior probability distribution of the data for a given K. Ln (K) obtained is a structure analysis and an ad hoc quantity distribution. B) Estimated population structure and genetic clusters of the 11 sites of Gaultheria pumila and 160 individuals with $\mathrm{K}=2$.
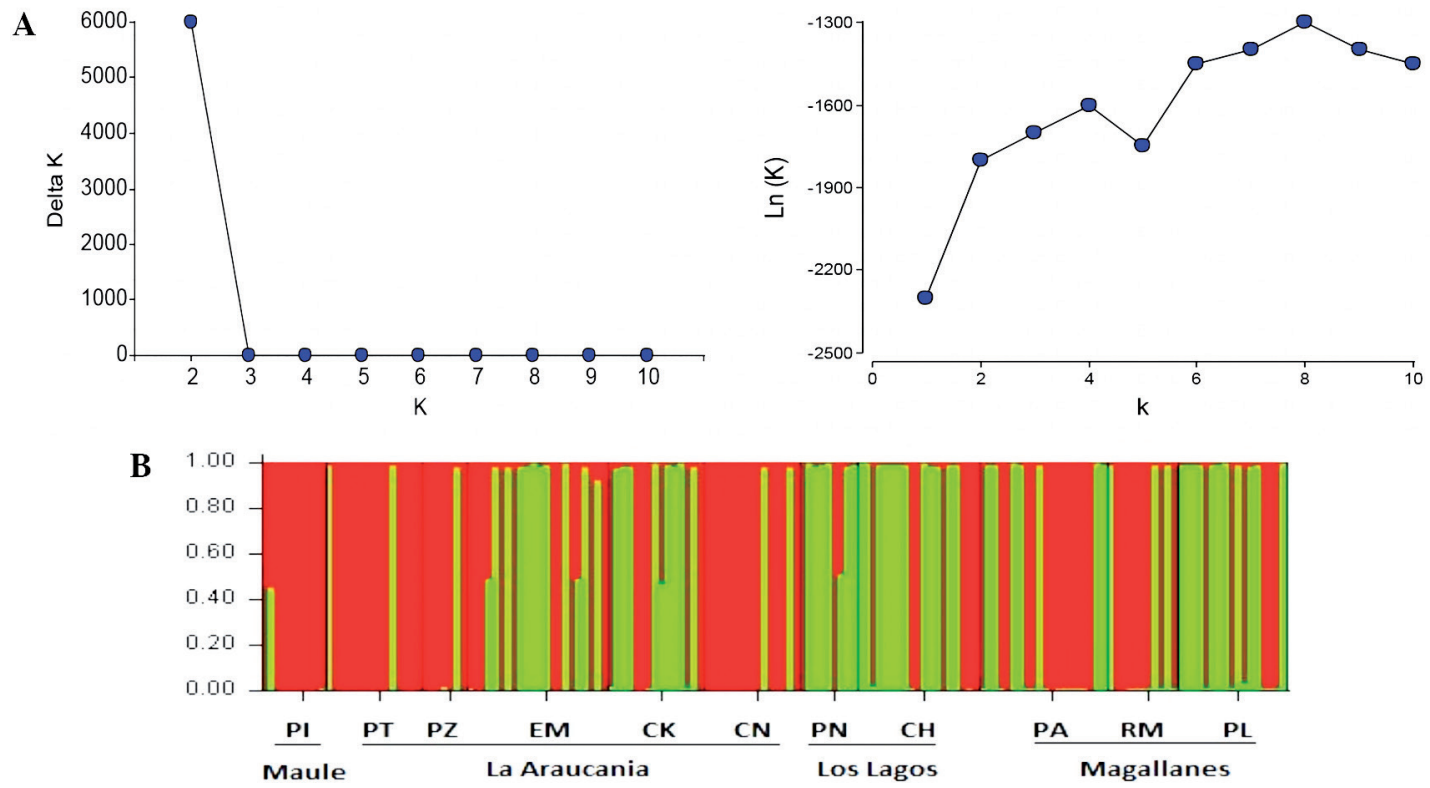

Maule Region: Parque Inglés (PI); La Araucanía Region: Parque de las Araucarias (PT), El Playón (PZ), El Mirador (EM), Centro de sky (CK), Parque Nacional Conguillío (CN); Los Lagos Region: Parque Nacional Puyehue (PN), Camino Puyehue (CH); Magallanes y la Antártida Chilena Region: Punta Arenas (PA), Reserva Nacional Magallanes (RM), Reserva Nacional Laguna Parrillar (PL).

\section{CONCLUSIONS}

The species shows a moderate level of genetic diversity and a very low level of genetic differentiation, indicating a high degree of genetic connectivity and gene exchange throughout its distribution. These results can be used to continue the domestication programs that have begun for the species, giving support to the selection of individuals from two genetic groups identified in this study.

\section{ACKNOWLEDGEMENTS}

The authors would like to thank the Ecuadorian Government (Senescyt) and the Facultad de Ingeniería Agronómica de la Universidad Técnica de Manabí for the scholarship to José Pico Mendoza. We are grateful to Maule Regional Government for supporting this research through the project Laboratorio Regional de Biotecnologías Aplicadas (VITOTRECH II-FIC-BIC 30.136.372-0). This research was also partially supported by institutional funds of the Company Sociedad de Investigación y Servicios BioTECNOS Ltda., from Chile.

\section{REFERENCES}

Ahmad, F., Khan, A.I., Awan, F.S., Sadia, B., Sadaqat, H.A., and Bahadur, S. 2010. Genetic diversity of chickpea (Cicer arietinum L.) germplasm in Pakistan as revealed by RAPD analysis. Genetics and Molecular Research 9:1414-1420. https://doi.org/10.4238/vol9-3gmr862.

Apte, G.S., Bahulikar, R.A., Kulkarni, R.S., Lagu, M.D., Kulkarni, B.G., Suresh, H.S., et al. 2006. Genetic diversity analysis in Gaultheria fragrantissima Wall. (Ericaceae) from the two biodiversity hotspots in India using ISSR markers. Current Science 91:1634-1640. 
Balloux, F. 2004. Heterozygote excess in small populations and the heterozygote-excess effective population size. Evolution 58:1891-1900.

Bantawa, P., Das, A., Ghosh, P.D., and Mondal, T.K. 2011. Detection of natural genetic diversity of Gaultheria fragrantissima landraces by RAPDs: An endangered woody oil bearing plant of Indo-China Himalayas. Indian Journal of Biotechnology 10:294-300.

Bassil, N.V.2012. Microsatellites markers: Valuable in Vaccinium L. International Journal of Fruit Science 12:288-293.

Benson, D.A., Karsch-Mizrachi, I., Lipman, D.J., Ostell, J., and Sayers, E.W. 2009. GenBank. Nucleic Acids Research 38:46-51.

Carrasco, B., Ávila, P., Pérez-Díaz, J., Muñoz, P., García, R., Lavandero, B., et al. 2009. Genetic structure of highland papayas (Vasconcellea pubescens (A. DC.) Badillo) cultivated along a geographic gradient in Chile as revealed by Inter Simple Sequence Repeats (ISSR). Genetic Resources and Crop Evolution 56:331-337.

Carrasco, B., Retamales, J.B., Quiroz, K., Garriga, M., and Caligari, P.D.S. 2013. Inter simple sequence repeat markers associated with flowering time duration in the Chilean strawberry (Fragaria chiloensis). Journal of Agricultural Science and Technology 15:1195-1207.

Chen, T., Huang, X., Zhang, J., Chen, Q., Liu, Y., Tang, H., et al. 2015. Genetic diversity and population structure patterns in Chinese cherry (Prunus pseudocerasus Lindl) landraces. Plant Molecular Biology Reporter 34:440-453. https://doi.org/10.1007/s11105-015-0934-2.

Delmas, C.E.L., Lhuillier, E., Pornon, A., and Escaravage, N. 2011. Isolation and characterization of microsatellite loci in Rhododendron ferrugineum (Ericaceae) using pyrosequencing technology. American Journal of Botany 98:120-122. https://doi.org/10.3732/ajb.1000533.

Dominguez, E. 2010. Flora de interés etnobotánico usada por los pueblos originarios : Aónikenk, Selk’nam, Kawésqar, Yagan y Haush en la Patagonia Austral. Dominguezia 26:19-29.

Doyle, J.J., and Doyle, J.L. 1990. Isolation of plant DNA from fresh tissue. Focus 12:13-15.

Earl, D.A., and vonHoldt, B.M. 2012. STRUCTURE HARVESTER: A website and program for visualizing STRUCTURE output and implementing the Evanno method. Conservation Genetics Resources 4:359-361. https://doi.org/10.1007\%2Fs12686-011-9548-7.

Emanuelli, F., Lorenzi, S., Grzeskowiak, L., Catalano, V., Stefanini, M., Troggio, M., et al. 2013. Genetic diversity and population structure assessed by SSR and SNP markers in a large germplasm collection of grape. BMC Plant Biology 13:13-39. https://doi.org/10.1186/1471-2229-13-39.

Fajardo, D., Morales, J., Zhu, H., Steffan, S., Harbut, R., Bassil, N., et al. 2013. Discrimination of American cranberry cultivars and assessment of clonal heterogeneity using microsatellite markers. Plant Molecular Biology Reporter 31:264271. https://doi.org/10.1007/s11105-012-0497-4.

Garcia-Gonzales, R., Pico-Mendoza, J., Quiroz, K., Carrasco, B., Cáceres, P., Chong-Perez, B., et al. 2018. Development and characterization of microsatellite markers in Gaultheria pumila Lf. (Ericaceae). Biological Research 51:42. https://doi.org/10.1186/s40659-018-0193-4.

Gepts, P. 2004. Crop domestication as a long-term selection experiment. Plant Breeding Reviews Vol. 24. Part 2: Long-term selection: Crops, animals, and bacteria. John Wiley \& Sons, Hoboken, New Jersey, USA.

Goudet, J. 1994. FSTAT (Version 1.2): A computer program to calculate F-Statistics. Journal of Heredity 86:485-486.

Hirai, M., Yoshimura, S., Ohsako, T., and Kubo, N. 2010. Genetic diversity and phylogenetic relationships of the endangered species Vaccinium sieboldii and Vaccinium ciliatum (Ericaceae). Plant Systematics and Evolution 287:75-84. https://doi.org/10.1007/s00606-010-0291-4.

Hoshino, A., Bravo, J., Nobile, P., and Morelli, K. 2012. Microsatellites as tools for genetic diversity analysis. p 149-170. In Caliskan, M. (ed.) Genetic diversity in microorganisms. Intech Open, London, Uk.

Kalinowski, S.T., Taper, M.L., and Marshall, T.C. 2007. Revising how the computer program CERVUS accommodates genotyping error increases success in paternity assignment. Molecular Ecology 16:1099-1106. https://doi.org/10.1111/j.1365-294X.2007.03089.x.

Kramer, A.T., Ison, J.L., Ashley, M.V., and Howe, H.F. 2008. The paradox of forest fragmentation genetics. Conservation Biology 22:878-885. https://doi.org/10.1111/j.1523-1739.2008.00944.x.

Liu, W.R., Qiao, W.L., Liu, Z.Z., Wang, X.H., Jiang, R., Li, S.Y., et al. 2013. Gaultheria: Phytochemical and pharmacological characteristics. Molecules 18:12071-12108. https://doi.org/10.3390/molecules181012071.

Lu, A.T., Quach, A., Wilson, J.G., Reiner, A.P., Aviv, A., Raj, K., et al. 2019. DNA methylation GrimAge strongly predicts lifespan and healthspan. Aging 11:303-327.

Luteyn, J.L. 2002. Diversity, adaptation, and endemism in neotropical Ericaceae: biogeographical patterns in the Vaccinieae. Botanical Review 68:55-87.

Medina, J., Davinson, F., Carrillo, R., y Rodriguez, M. 2009. Simbiosis micorrícica presente en Nothofagus dombeyi (Mirb.) Oerst y Gaultheria pumila (L. fil) Middleton. Especies colonizadoras de escoriales volcánicos en la Región de La Araucanía, Chile. I Congreso Nacional de Conservación de la Biodiversidad a través su Uso, Sucre. 23 al 25 Noviembre. Programa de Investigación Estratégica en Bolivia (PIEB), La Paz, Bolivia. 
Middleton, D.J., and Wilcock, C.C. 1990. Chromosome counts in Gaultheria and related genera. Edinburgh Journal of Botany 47(3):303-313.

Mukhopadhyay, M., Bantawa, P., Mondal, T.K., and Nandi, S.K. 2016. Biological and phylogenetic advancements of Gaultheria fragrantissima: Economically important oil bearing medicinal plant. Industrial Crops and Products 81:91-99.

Oddou-Muratorio, S., Vendramin, G.G., Buiteveld, J., and Fady, B. 2009. Population estimators or progeny tests: what is the best method to assess null allele frequencies at SSR loci? Conservation Genetic 10:1343. https://doi.org/10.1007/s10592-008-9648-4 .

Peakall, R., and Smouse, P. 2006. GENALEX 6: genetic analysis in Excel. Population genetic software for teaching and research. Molecular Ecology Notes 6:288-295. https://doi.org/10.1111/j.1471-8286.2005.01155.x.

Pérez, V., Larrañaga, N., Abdallah, D., Wünsch, A., and Hormaza, J.I. 2020. Genetic diversity of local peach (Prunus persica) accessions from La Palma Island (Canary Islands, Spain). Agronomy 10:457.

Pritchard, J.K., Stephens, M., and Donnelly, P. 2000. Inference of population structure using multilocus genotype data. Genetics 155:945-959.

Rodriguez, R., Marticorena, C., Alarcón, D., Baeza, C., Lohengrin, C., Finot, V.L., et al. 2018. Catálogo de las plantas vasculares de Chile. Gayana Botanica 75:1-430.

Salgado, P., Prinz, K., Finkeldey, R., Ramírez, C.C., and Vogel, H. 2017. Genetic variability of Aristotelia chilensis (“maqui”) based on AFLP and chloroplast microsatellite markers. Genetic Resources Crop Evolution 64:2083-2091.

Teillier, S., and Escobar, F. 2013. Revisión del género Gaultheria L. (Ericaceae) en Chile. Gayana Botánica 70:136-153. https://doi.org/10.4067/S0717-66432013000100014.

Villagra, E., Campos-Hernandez, C., Caceres, P., Cabrera, G., Bernardo, Y., Arencibia, A., et al. 2014. Morphometric and phytochemical characterization of chaura fruits (Gaultheria pumila): A native Chilean berry with commercial potential. Biological Research 47:1-8. http://dx.doi.org/10.1186/0717-6287-47-26.

Wang, S., Li,Z., Jin, W., Xiang, F., Xiang, J., and Fang, Y.2016. Development and characterization of polymorphic microsatellite markers in Rhododendron simsii (Ericaceae). Plant Species Biology 32:1-4. https://doi.org/10.1007\%2Fs12041-018-0931-y.

Wang, N., Qin, Z.C., Yang, J.B., and Zhang, J.L. 2010. Development and characterization of 15 microsatellite loci for Rhododendron delavayi Franch. (Ericaceae). HortScience 45:457-459.

Wilkin, J.E., Shamoun, S.F., Ritland, C., Ritland, K., and El-Kassaby, Y.A. 2005. Population genetics of Gaultheria shallon in British Columbia and the implications for management using biocontrol. Canadian Journal of Botany 83:501-509. https://doi.org/10.1139/b05-039.

Yeh, F., Rong-cai, Y., Boyle, T., and Freeware, M.W. 1999. POPGENE, Microsoft Window-based freeware for population genetic analysis. Release 1.31. University of Alberta, Edmonton, Alberta, Canada. 